
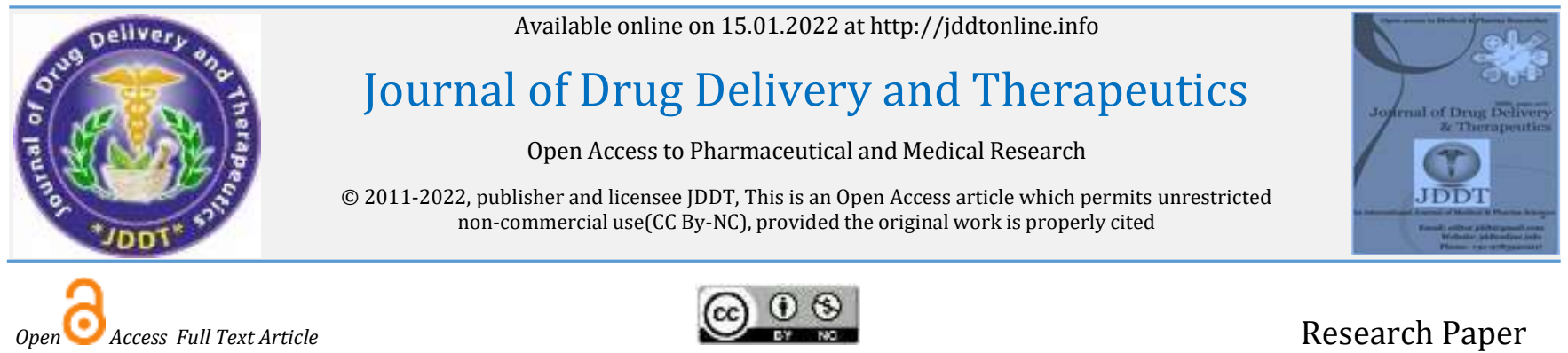

Research Paper

\title{
Simulation method of brushing teeth with bass technique in elementary school children: Is it effective?
}

\author{
Melkisedek O. Nubatonis ${ }^{1}$, Agusthinus Wali ${ }^{2}$ Mery Novaria Pay ${ }^{3}$, Merniwati S. Eluama ${ }^{4 *}$ \\ 1,2,3,4 Department of Dental Health, Poltekkes Kemenkes Kupang, Indonesia
}

\section{Article Info:

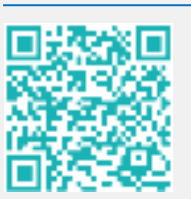 \\ Article History: \\ Received 12 November 2021 Reviewed 19 December 2021 Accepted 28 December 2021 Published 15 January 2022}

\section{Cite this article as:}

Nubationis OM, Wali A, Pay NM, Eluama SM, Simulation method of brushing skills teeth with bass technique in elementary school children: Is it effective?, Journal of Drug Delivery and Therapeutics. 2022; 12(1):30-32

DOI: $h$ ttp://dx.doi.org/10.22270/jddt.v12i1.5272

*Address for Correspondence:

Melkisedek P. Nubationis, Department of Dental Health, Poltekkes Kemenkes Kupang, Indonesia

\section{Abstract}

Background: Dental and oral disease is the highest disease that people complain about in the province of East Nusa Tenggara where the prevalence of dental caries is $54.9 \%$. Specifically for children aged 4-9 it was $50.0 \%$ and children aged 10-14 were $41.4 \%$. This is related to the data on the behavior of brushing teeth properly after breakfast and before going to bed at night which is only $3.7 \%$. Objective: This study was to analyze the effect of the simulation method of brushing teeth using the bass technique on the improvement of tooth brushing skills in elementary school children. Method: This study used a pre-experimental design with a pretest and posttest with a one group design. The research was conducted at SDN 2 Baumata Timur, Taebenu District, Kupang Regency. The research sample was taken by purposive sampling technique, as many as 100 students. The instrument for collecting data on brushing teeth skills used an observation sheet. Analysis of the research data using the Wilcoxon test. Result: simulation method of brushing teeth with bass technique is effective in improving brushing skills $(\mathrm{p}<0.001)$. Conclusion: The simulation method of brushing teeth with the bass technique is effective in improving the brushing skills of elementary school children.

Keywords: Simulation method, bass technique, brushing skills

\section{INTRODUCTION}

Dental and oral health is a very important part of overall health, dental and oral health in Indonesia needs to be considered because dental and oral disease is the highest disease that people complain about.1,2 Dental health problems such as dental caries, bad breath, and periodontitis are often suffered by children. Dental caries if allowed to continue will experience an infection in the mouth and cause pain. ${ }^{3,4}$ Some children only know several methods of brushing their teeth, such as vertical and horizontal methods, while other techniques such as the bass technique or other modification techniques are not known so that dental hygiene is lacking, while brushing teeth with the bass technique is more effective in cleaning teeth and mouth.5,6

Basic health research in 2018 showed that the population of Indonesia who suffered from dental and oral problems was $57.6 \%$ while dental and oral health problems in the province of East Nusa Tenggara were $54.9 \%$. Specifically on dental health problems in children, the prevalence of dental and oral caries was $50.0 \%$ in children aged 4-9 while the prevalence of caries in children aged $10-14$ was $41.4 \% .^{7}$

High dental health problems, this is related to data on brushing teeth behavior which every day, it was found that most of the Indonesian population brushed their teeth properly after breakfast and before going to bed at $2.8 \%$ while the people of East Nusa Tenggara brushed their teeth properly after eating breakfast and before going to bed at night only $3.7 \% .^{7,8}$

The main factor that can cause dental caries is the presence of bacteria that can cause dental caries, namely streptococcus and lactobacilli types, foods that we often consume sweet and sticky foods such as candy and chocolate greatly facilitate the occurrence of dental caries, and irregular tooth shape. In addition to several other factors also contribute to dental caries, namely the level of dental and oral hygiene, frequency of food, gender and age. ${ }^{9-11}$

Efforts are made to clean teeth from dental caries and plaque by brushing their teeth. Brushing teeth properly can improve the dental hygiene status of children as an effort to prevent dental disease. ${ }^{12,13}$ Brushing teeth can be done by several methods using the bass method. Bass technique is a technique for brushing teeth which is done by placing a $45^{\circ}$ toothbrush on the root of the tooth and then pressing it slowly while making small rotating movements. ${ }^{14}$

\section{MATERIALS AND METHODS}

The research design used was pre-experimental with onegroup pre-post test design. This research was conducted to determine the causal relationship by involving a group of subjects. The subject group was observed before the intervention, then observed after the intervention. ${ }^{15}$ 
The independent variable in this study was the simulation method of brushing teeth using the bass technique, while the dependent variable was brushing skills. The instrument in this study for the variable method of brushing teeth using the bass technique by making checklist observations on children's brushing skills, while the tools used for simulation are phantom teeth, toothbrush, toothpaste. Analysis of research data used to test the influence of two variables, namely the Wilcoxon test.

\section{RESULT}

Table 1. Frequency distribution of respondent characteristics by Gender

\begin{tabular}{lcc}
\hline Variable & $\mathrm{N}$ & Percentage (\%) \\
\hline Male & 50 & 50.0 \\
Female & 50 & 50.0 \\
Total & 100 & 100 \\
\hline
\end{tabular}

Table 1 shows that characteristics based on gender, the percentage is the same between male $50 \%$ and female $50 \%$.

Table 2. Frequency distribution of respondent characteristics by grade in elementary school

\begin{tabular}{lcc}
\hline Grade & N & Percentage (\%) \\
\hline Grade 2 & 19 & 19 \\
Grade 3 & 18 & 18 \\
Grade 4 & 17 & 17 \\
Grade 5 & 25 & 25 \\
Grade 6 & 21 & 21 \\
Total & 100 & 100 \\
\hline
\end{tabular}

Table 2 shows that the largest percentage is grade 5 by $25 \%$ and the least percentage is grade 4 at $17 \%$.

Table 3. The results of the effectiveness test of brushing teeth before and after the intervention

\begin{tabular}{lcc}
\hline Brushing teeth & $\mathrm{N}$ & $\mathrm{p}$-value \\
\hline Pretest & 100 & 0.001 \\
Postest & 100 & \\
\hline
\end{tabular}

*Wilcoxon test

Table 3 shows that the results of the test of the effectiveness of the simulation method of brushing teeth using the bass technique on children's brushing skills obtained a p-value of 0.001 which means that the simulation method of brushing teeth using the bass technique is effective in improving brushing skills.

\section{DISCUSION}

The research was conducted at SDN 2 Baumata Timur, Taebenu District, Kupang Regency, to determine the effect of the simulation method of brushing teeth using the bass technique on brushing skills. Table 1 shows the distribution of the frequency of elementary school children by gender, the percentage is the same between $50 \%$ male and 50\% female. This is because the motivation for parents to send their children to school is very high and the characteristics of the children around the SDN 2 Baumata Timur area have almost the same number of male as female.

Based on table 2, it shows the frequency distribution of elementary school children by gender, the largest percentage is grade 5 at $25 \%$ and the least percentage is grade 4 at $17 \%$, this is because the number of registrations for elementary school children every year often changes and cannot determined how many new students enroll each year.
Based on table 2, showing the results of the simulation method of brushing teeth using the bass technique on brushing skills, $p$ $=0.000(\mathrm{p}<0.05)$ so that it can be interpreted that the simulation method of brushing teeth using the bass technique is effective in improving the brushing skills of elementary school children. This is because previously children brushed their teeth but did not use the right and correct method of brushing their teeth so that it could lead to dental and oral health problems, including dental caries, abrasion and tartar, so counseling and simulation of brushing teeth using the bass method was needed. This simulation of brushing teeth can encourage children to find out which parts are not clean and what steps are wrong, so that children can be encouraged to clean the parts that are still dirty more thoroughly and can correct the wrong steps. ${ }^{16,17}$ The Simulation method is a form of giving method that is arranged in such a way that the learning process is carried out by a group or community. 18

The results of research on the effect of the simulation method of brushing teeth using the bass technique on children's brushing skills before and after this counseling, are in line with research conducted by Sari et al. which stated that tooth brushing skills and oral hygiene were good for most children. after conducting health education and simulation of brushing teeth with bass modification techniques. ${ }^{17}$ As for another study, according to Rizkika et al. said that it was very effective to brush teeth using the Bass method to reduce index debris. ${ }^{19}$

\section{CONCLUSION}

Based on the results of the study, it can be concluded that there is simulation method of brushing teeth with the bass technique is effective in improving the brushing skills of elementary school children.

\section{ACKNOWLEDGEMENTS}

The authors thank to Poltekkes Kemenkes Kupang for funding this research, all participants and research assistants.

\section{CONFLICT OF INTEREST}

The authors declare that they have no conflict interests.

\section{ETHICAL CLEARANCE}

All participants were signed the informed consent prior to the data collection.

\section{REFERENCES}

1. Purnama T. Effectiveness of Counseling with Chair Side Talk Ministry of Religion. Int Res J Pharm Med Sci. 2019; 2(6):15-7.

2. Ngatemi, Purnama T. Dental Health Handbook as Parents Monitoring in the Formation of Independence for Brushing Teeth in Early Childhood. Indian J Public Heal Res Dev. 2020; 11(1). https://doi.org/10.37506/v11/i1/2020/ijphrd/193920

3. Purnama T, Fadjeri I, Widiyastuti R. Model Mentoring Teachers and Parents as an Efforts for Brushing Teeth Behavior in Preschool Children. Indian J Forensic Med Toxicol. 2020; 14(4):3511-6.

4. Fadjeri I, Budiarti R, Purnama T. Dental Care Interventions as Efforts to Reduce PUFA Index and Improve Nutritional Status in Children aged 912 Years in Orphanages. Med Leg Updat. 2021; 21(1):366-71.

5. Ilyas M, Ashraf S, Jamil H. Tooth brushing techniques. Prof Med J. 2018; 25(01):135-9. https://doi.org/10.29309/TPMJ/18.4429

6. Harnacke D, Mitter S, Lehner M, Munzert J, Deinzer R. Improving oral hygiene skills by computer-based training: a randomized controlled comparison of the modified Bass and the Fones techniques. PLoS One. 2012; 7(5):e37072. https://doi.org/10.1371/journal.pone.0037072

7. Kemenkes RI. Hasil utama riskesdas 2018. Jakarta.

8. Purnama T, Rasipin N. Tedi's Behavior Change Model to Improving 
Brushing Teeth Behavior Parents. J Appl Heal Manag Technol. 2020; 2(1):1-12.

9. Al-Shahrani MA. Microbiology of dental caries: A literature review. Ann Med Health Sci Res. 2019;

10. Wang Y, Wang S, Wu C, Chen X, Duan Z, Xu Q, et al. Oral microbiome alterations associated with early childhood caries highlight the importance of carbohydrate metabolic activities. MSystems. 2019; 4(6):e00450-19. https://doi.org/10.1128/mSystems.00450-19

11. Tarigan R. Karies gigi. Jakarta EGC. 2013;

12. Wiradona I, Widjanarko B, Syamsulhuda BM. Pengaruh Perilaku Menggosok Gigi terhadap Plak Gigi Pada Siswa Kelas IV dan V di SDN Wilayah Kecamatan Gajahmungkur Semarang. Pengaruh Perilaku Menggosok Gigi terhadap Plak Gigi Pada Siswa Kelas IV dan V di SDN Wil Kec Gajahmungkur Semarang. 2016; 8(1):59-68.

13. Purnama T, Rasipin R, Santoso B. Pengaruh Pelatihan Tedi's Behavior Change Model pada Guru dan Orang Tua terhadap Keterampilan Menggosok Gigi Anak Prasekolah. Qual J Kesehatan. 2019; 13(2):75-81. https://doi.org/10.36082/qjk.v13i2.80

14. Hiranya MP, Eliza $H$, Neneng N. Ilmu pencegahan penyakit jaringan keras dan jaringan pendukung gigi. Jakarta EGC. 2011; 104.

15. Nursalam S. Metodologi penelitian ilmu keperawatan pendekatan praktis. Jakarta Salemba Med. 2013;
16. Ngatemi TP. Counseling with Tooth Brushing Demonstration Method as an Effort to Improve Tooth Brushing Skills and the Status of Dental and Oral Hygiene in Early Childhood at School. Med Leg Update. 2021; 21(1):684-7.

17. Sari SAN, Efendi F, Rachmawati PD. Pengaruh Pendidikan Kesehatan Metode Simulasi Menggosok Gigi Teknik Modifikasi Bass dengan Ketrampilan dan Kebersihan Gigi Mulut pada Anak Mi At-Taufiq Kelas V. Indonesian J Community Heal Nurs. 2012; 1(1).

18. Perry S, Bridges SM, Burrow MF. A review of the use of simulation in dental education. Simul Healthc. 2015; 10(1):31-7. https://doi.org/10.1097/SIH.0000000000000059

19. Rizkika N, Baehaqi M, Putranto RR. Efektivitas menyikat gigi dengan metode bass dan horizontal terhadap perubahan indeks plak pada anak tunagrahita. Odonto Dent J. 2014; 1(1):29-33. https://doi.org/10.30659/odj.1.1.29-33 